\title{
The impact of earnings-announcement timing on technical analysis signal: The case of Indonesia
}

\author{
Dedhy Sulistiawan ${ }^{1}$ \\ ${ }^{1}$ University of Surabaya, Kalirungkut Street, Surabaya, 60293, East Java, Indonesia
}

\section{A R T I C L E IN F O}

Article history:

Received 8 May 2015

Revised 7 July 2015

Accepted 6 August 2015

\section{JEL Classification: M19}

Key words:

Technical Analysis,

Timeliness,

Reporting Lag,

Earnings Announcement.

DOI:

10.14414/jebav.v18i2.446

\begin{abstract}
A B S T R A C T
This study discusses technical analysis signal and earnings-announcements timing. Technical analysis signal is used to capture price reaction around earnings announcement dates. Technical analysis is selected because it is potential for competing information as fundamental information in emerging market, especially in Indonesian stock market. The longer reporting lag will result in a tendency of bigger information leakage which makes price reaction before announcements stronger. That reaction produces a reliable technical analysis signal. By using Indonesian stock market data, the results show that (1) technical analysis signal generates bigger (lower) return for late (earlier) reporting, and (2) reporting lag positively affects the performance of technical analysis signal that emerge before annual earnings announcements. These findings indicate a tendency of bigger information leakage for companies that delay earnings announcements. It contributes to building a bridge between technical analysis and earnings-announcement timing studies.
\end{abstract}

\begin{abstract}
A B S T R A K
Penelitian ini membahas analisis teknis dan waktu pengumuman laba. Sinyal analisis teknis digunakan untuk menggambarkan reaksi harga sekitar tanggal pengumuman laba. Analisis teknis dipilih karena potensi persaingan informasi sebagai informasi yang sangat penting di pasar yang berkembang, terutama di pasar saham Indonesia. Reporting lag yang lebh lama akan menghasilkan kecenderungan kebocoran informasi lebih besar yang membuat reaksi terhadap harga sebelum pengumuman kuat. Reaksi tersebut menghasilkan sinyal analisis teknis yang handal. Dengan menggunakan data pasar saham Indonesia, hasilnya menunjukkan bahwa (1) sinyal analisis teknis menghasilkan lebih besar (lebih rendah) return for late (lebih awal) pelaporan, dan (2) reporting lag yang positif mempengaruhi kinerja sinyal analisis teknis yang muncul sebelum pengumuman laba tahunan. Temuan ini menunjukkan kecenderungan kebocoran informasi lebih besar bagi perusahaan yang menunda pengumuman laba. Ini memberikan kontribusi untuk menjembatani studi analisis teknis dan penentuan waktu pengumuman laba.
\end{abstract}

\section{INTRODUCTION}

The main objective of this study is to provide empirical evidence of the relation between earningsannouncement timing and technical analysis signal. This research is the extension of Sulistiawan and Hartono (2014). They provide evidence that technical analysis signal before earnings announcements can generate profitable return. This study develops the idea by analyzing the timing of earnings announcements to explain the profitability of technical analysis signal.

This study is important for several reasons.
The first reason, technical analysis tends to produce better performance in developing market than that in developed market (Fifield et al. 2005; McKenzie 2007; Hartono and Sulistiawan, 2014). The second, technical analysis is competing information to fundamental information, including accounting information (Franchis et al. 2002; Flanegin and Rudd 2005; Sulistiawan et al. 2014). The third, technical analysis signal is useful in anticipating earnings announcements (Sulistiawan and Hartono, 2014; Sulistiawan et al. 2014).

Using international data, Hartono and Sulis-

* Corresponding author, email address: ${ }^{1}$ dedhy@ubaya.ac.id. 
tiawan (2015) also provide evidence that technical analysis become more important when global stock markets decline. The need of competing information increases when accounting quality decreases. Later (earlier) announcements will produce lower (higher) information content. Delaying accounting information also stimulates the use of competing information. In this case, technical analysis is needed.

Using market microstructure theory, this study believes that there are two types of market participants, noise traders and informed investors. Informed investors have access to private information. They can get benefit from preannouncement activities (Black 1986). This study believes that noise traders may use technical analysis signal to detect informed-investors reaction before earnings announcements, especially for late announcers. That statement is supported by the study of Sulistiawan and Hartono (2014). They give evidence that investors react before earnings announcements, and their activities are captured by technical analysis. This study develops that idea by using earnings-announcement timing. The earlier (later) announcers generate lower (higher) return based on technical analysis signal before earnings announcements.

Previous studies provide evidence that good (bad) news will be announced earlier (later), for example Kross (1982) in US, Whittred (1980) in Australia, and Haw et al. (2000) in China. This study also develops those previous researches by using earnings-announcement timing as the determinant of technical analysis performance. Earlier (later) earnings announcements are expected to reduce (increase) information leakage risk so that it produces lower (higher) reaction before earnings announcements. Technical analysis signal produce better (worse) performance in detecting price reaction when reporting lag is longer (shorter).

In general, these research give evidence that (1) later (earlier) announcers produce higher (lower) technical analysis return, (2) reporting lag positively affect technical analysis performance. Price movements before earnings announcements generate reliable technical analysis signals, especially in "buy signal" sample. These results suggest that the tendency of information leakage of late announcers can be detected by technical analysis signal.

The main purpose of this study is to examine the impact of earnings-announcement timing on technical analysis signal using Indonesian data.
Earnings-announcement timing is represented by two factors; there are (1) the timeliness of earnings announcements, and (2) reporting lag. The first issue is company intention to announce earnings based on stock-market authority rule. The second issue is related to the speed of announcements. This study use technical analysis performance to show that preannouncements reaction can be detected by technical analysis signal. It means that noise traders can use stock price to anticipate informed investors activities before earnings announcements.

There are several contributions in this study. First, this research develops earnings announcement studies. The studies on earningsannouncement timing have been widely discussed, but the impact on technical analysis performance around earnings announcements is only showing a prospective. This study bridges the gap between earnings-announcements timing and technical analysis studies.

Second, this study develops the issue of competing information to accounting information by using technical analysis signal. Francis et al. (2002) stimulate the idea of competing information in earnings announcements and the study of Sulistiawan et al. (2014) using technical analysis signals as competing information. This study expands that research by adding reporting lag variable. That is the duration between financial report date and its announcements.

Third, this study supports stock market regulators to make policy related to the timing of earnings announcements. The regulator is expected to do more discipline enforcement on announcementtiming policy. And fourth, this study proposes trading strategies around earnings-announcement dates for retail investors. Retail investors can use charts to detect informed investors reaction around earnings-announcement dates.

\section{THEORETICAL FRAMEWORK AND HYPO- THESES}

This study uses market microstructure theory to develop the relation between two issues, namely (1) earnings-announcement timing, which has been widely discussed in accounting (Sengupta, 2004), and (2) technical analysis research (Fifield et al. 2005; McKenzie 2007, Metgalchi et al. 2012). Those issues are on different research stream. This study attempts to combine those issues.

Based on the theory, informed investors use their access to exploit inside information before announcements. Using technical analysis, noise traders may detect preannouncement reaction of 
informed investors. The study of Sulistiawan and Hartono (2014) gives the evidence about that phenomenon. This study develops that idea to explain the performance of technical analysis signal around earnings announcements using earningsannouncement timing.

The Impact of Timeliness Announcements to Technical Analysis Performance

According to capital market authority in Indonesia, companies' financial statements must be submitted no later than the end of the third month after the date of financial statement. It means that the maximum reporting lag is three months. Reporting lag from managements will give different signals to the market. When managers have crucial private information, they have obligation to share new information to the market to minimize information asymmetry. It means that delaying announcements will decrease relevancy of information. In Indonesia, Wirakusuma (2006) presents how timely reports affect earnings informativeness. Hence, the extent of an earnings announcement will provide "useful" information to market participants that it should be a function not only of the nature of information released but also when it is released (Sengupta 2004). Timely financial statement information helps in efficient allocation of resources by reducing dissemination of asymmetric information. Timely announcements may also mitigate insider trading, leaks and rumors in the market.

Decreasing accounting quality improves usefulness of competing information. As competing information, technical analysis signal utilizes reaction before earnings announcements, especially reaction on late earnings announcement. Late announcements stimulate more informed investors to take advantage of their superior information. Their activities before earnings announcements can be detected by noise traders by using technical analysis. The reliability of signal is presented by technical analysis performance. The higher (lower) technical analysis return represents more (less) reliable signal. Based on that idea, the first hypothesis is presented as follows.

H1: Late (early) earnings announcements produces higher (lower) return based on technical analysis signal before earnings announcements.

\section{Reporting Lag and Technical Analysis Perfor- mance}

It is apparent that earnings information is not the only superior information. It is said so because there is much information outside financial statement that is used by investors (Francis et al. 2002). Managers should set the earnings release date based on their evaluation of potential benefits (and costs) of releasing earnings information quickly. This behavior affects the reporting lag. However, it is longer for firms with greater block ownership (Sengupta 2004). This is also consistent with the argument that firms respond to pressures from investors to release earnings quickly. Firms that have large block ownership, however, are less susceptible to such pressures and they have little incentive to produce higher earnings informativeness.

Reporting lag stimulates the tendency of information leakage. In this condition, technical analysis may be useful. Technical analysis is competing information for fundamental analysis, especially in anticipating short-term price reaction (Flanegin and Rudd 2005) present that technical analysis is competing information. Franchis et al. (2002) also argue that idea. In Indonesia, Sulistiawan et al. (2014) give evidence about the role of competing information to earnings announcements.

This study predicts that the role of technical analysis is increasing when reporting lag is high. Reporting lag decrease information content on earnings-announcement dates, while it stimulates preannouncements reaction. In effect, the ability of technical analysis signal to generate profits will increase before earnings announcements. The speed of earnings announcements will improve the quality of accounting information. High quality of accounting information reduces the usefulness of competing information. Technical analysis as competing information decreases its usefulness when reporting lag is short. To test the hypothesis, this study uses absolute speed as contrary term of reporting lag. The greater reporting lag presented, competing information become more important.

Supporting reporting lag phenomenon in Indonesia, Landsman et al. (2012) shows that Indonesia is a country that presents its reporting lag which is relatively larger than other countries. It means that those reporting lag can be exploited by technical analysis signal before earnings announcements. This study predicts that reporting lag stimulates information leakage, and the reaction before announcements can be detected by technical analysis signal. According to that prediction, the hypothesis can be stated as follows.

H2: Reporting lag positively affect return based on technical analysis signal before earnings announcements. 


\section{RESEARCH METHOD \\ Data Collection}

This study uses Indonesian stock market data. Indonesian market is a developing market and many researches show that earnings informativeness is low in Indonesia (Landsman et al. 2012) while the stock price produces high quality technical analysis signal (McKenzie 2007; Hartono and Sulistiawan 2014 \& 2015). Those phenomena improve the context of this study.

Listed companies in Indonesia Stock Exchange (IDX) are selected. Earnings-announcement dates are determined when firms formally submit their annual financial statement to stock exchanges authority. Confounding effect should be eliminated to isolate the effect of earnings announcements. Dividend, stock split/reverse, right issue, and merger are corporate action. This study also eliminates those actions because those may cause market reaction. The dates are used here as a surrogate of earnings-announcement dates commonly used in US stock market.

\section{Variables and Measurements}

\section{Variables and the Measurements}

Earnings-announcement dates are determined based on submitting date to IDX. Based on this information, Status $\mathrm{s}_{\mathrm{i}, \mathrm{t}}$ and $\mathbf{R l}_{\mathrm{i}, \mathrm{t}}$ can be determined. Status $_{i, t}$ represent the timeliness of earnings announcements. It is a categorical variable, with value 1 (0) for late (early) announcer $i$ in year t. Companies that announce before (after) March $31^{\text {st }}$ are (earlier) later announcers, because they are (timely) not timely based on Indonesian stock market regulation. $\mathrm{Rl}_{\mathrm{i}, \mathrm{t}}$ is reporting lag firm $\mathrm{i}$ in year $\mathrm{t}$. Reporting lag is determined by the duration between earnings announcement and financial-statement date. The data of earnings-announcement dates are acquired from Indonesian Capital Market Library (ICAMEL).

To determine buy (sell) signal before earnings announcements, this study needs to create charts of firms that are analyzed. This study uses SMA5 as technical analysis indicator because it is very popular in practice and widely use in investing communities. Many providers of technical analysis software also use that indicator as a default indicator. SMA5 also gives the greatest probability of producing returns over longer period (Milionis and Papanagiotou 2008), and the use of a single indicator and simple is better than composite indicator (Metgalchi et al. 2012). SMA5 for firm $i$ in year $t$ can be measured as follows.

$S M A 5_{i, t}=\left(P 5_{i, t}+P 4_{i, t}+P 3_{i, t}+P 2_{i, t}+P 1_{i, t}\right) / 5$.
$P 5_{i, t}$ is stock price of firm i on 5 days ago in year t. $P 1_{i, t}\left(P 2_{i, t}\right)$ is stock price of firm i on 1 (2) days ago in year $t$. Based on that measurement, SMA5 chart is generated and combined with stock price chart. Technical analysis signal can be produced using this equation.

$t_{B S i}=\left(P_{0, i}>S M A 5_{0, i}\right.$ where $\left.P_{-1, i}<S M A n_{-1, i}\right)$.

$t_{S S i}=\left(P_{0, i}<S M A n_{0, i}\right.$ where $\left.P_{-1, i}>S M A n_{-1, i}\right)$.

The notation $\mathbf{t}_{\mathrm{BSi}}\left(\mathbf{t}_{\mathrm{SSi}}\right)$ is a signal to buy (sell) that appears on the stock $i$. Buy signal occurs when the stock price the day 0 of firm i $\left(\mathrm{P}_{0, \mathrm{i}}\right)$ cross up SMA5 line of firm $i$ on the day $0\left(\mathrm{SMA} 5_{0, \mathrm{i}}\right)$ where in the previous day stock price of firm $\mathrm{i}\left(\mathrm{P}_{-1, i}\right)$ is lower than its simple moving average $\left(\mathrm{SMAn}_{-1, \mathrm{i}}\right)$. This study uses one signal before earnings announcement dates as an opening signal and one signal after that as a closing signal.

Technical analysis return is calculated based on the difference of stock price between those signals. $R t b_{i, t}$ is technical analysis return before earnings announcement for firms $i$ in year $t$. If technical analysis signal is $\mathbf{t}_{B S i}$ then $\mathbf{R} t \mathbf{b}_{\mathbf{i}, t}$ equal to equation (4). If the signal is $t_{S S i}$ then $R t b_{i, t}$ equal to equation (5).

$\operatorname{Rtb}_{B S i, t}=\left(P_{a, i, t}-P_{b, i, t}\right) / P_{b, i, t}$

$R t b_{S S i, t}=-\left[\left(P_{a, i, t}-P_{b, i, t}\right) / P_{b, i, t}\right]$

Notation $\mathbf{R t b}_{\mathrm{SBi}, \mathrm{t}}\left(\mathbf{R t b}_{\mathrm{SSi}, \mathrm{t}}\right)$ represent that technical analysis return is generated from price on buy (sell) signal before earnings announcements on stock $\mathrm{i}$ on year $\mathrm{t}$ compared to price on sell (buy) signal after earnings announcements. Yet, $\mathrm{P}_{\mathrm{b}, \mathrm{i}}\left(\mathrm{P}_{\mathrm{a}, \mathrm{i}}\right)$ is the closing price at the time itsBi and tsli before (after) earnings announcements. In measuring return, this study not only use closing price but also highlow price on the day of $t_{\mathrm{SBi}}$ (or $\mathrm{t}_{\mathrm{Sli}}$ ). Return based on high-low daily price is also needed to anticipate daily price fluctuation. To isolate technical analysis return around earnings announcements, this study adjusts technical analysis return by (1) market return, and (2) risk and market return. In this procedure, stock beta is calculated using one-year estimation based on daily data.

The descriptive statistics of variables are presented in Table 1. Based on the data on Table 1, all of technical analysis returns are positive. It means that returns based on technical analysis signal before earnings announcements are reliable. Based on the data, the average of reporting lag $\left(\mathrm{Rl}_{\mathrm{i}, \mathrm{t}}\right)$ is almost 60 days. It means, on average, observed sample already announces their earnings in two-months after fiscal year. This is faster than the requirements. This study predicts that delaying announcements degrade those technical analysis performances. 
Table 1

Descriptive Statistics

\begin{tabular}{lrrrrr}
\hline & N & Minimum & Maximum & Mean & Std. Deviation \\
\hline Rli,t & 1016 & 15.00 & 123.00 & 59.3494 & 12.44982 \\
Signal & 1016 & 0.00 & 1.00 & 0.5669 & 0.49574 \\
Timeliness & 1016 & 0.00 & 1.00 & 0.8425 & 0.36443 \\
Rtbi,t,close & 1016 & -0.28 & 2.61 & 0.0442 & 0.17237 \\
Rtbi,t,hl & 1016 & -0.28 & 2.95 & 0.0663 & 0.18248 \\
ExRtbi,t,close & 1016 & -0.28 & 2.52 & 0.0360 & 0.16183 \\
ExRtbi,t,hl & 1016 & -0.28 & 2.85 & 0.0535 & 0.17116 \\
ARtbi,t,close & 912 & -.025 & 2.61 & 0.0365 & 0.16798 \\
ARtbi,t,hl & 427 & -0.12 & 2.01 & 0.0397 & 0.12983 \\
\hline
\end{tabular}

Rli,t is reporting lag of firm i in year t. Signal is a binary indicator variable equal to one if buy signal, zero otherwise. Timeliness is a binary indicator variable equal to one if late, zero otherwise. Rtbi,t,close (Rtbi,t,hl) is calculated based on the difference between the closing (high and low) price on technical signal day before and after the earnings announcement. ExRtbi,t, (ExRtbi,t,hl) is Rtbi,t (Rtbi,t,hl) after adjusted by market return. ARtbi,t, (ARtbi,t,hl) is Rtbi,t (Rtbi,t,hl) after adjusted by expected return based on market model.

\section{Hypotheses Testing}

This study uses firm level in the measurement of variables where subscript i represent the stock of a company, and $t$ represents the year. H1 predicts that $R t b_{i, t, l a t e}>R t_{b t} t_{i, t, e a r l y}$. Rtbt $t_{i, t}$ is return based on technical analysis signal before earnings announcement date for stock $i$ for year $t$. $R t b t_{i, t, l a t e}\left(R t b t_{i, t e a r l y}\right)$ is $R t b t_{i, t}$ for late (early) announcer. This study also complements the test by controlling size and technical analysis signal. Previous studies show that firm's size determines the reaction around earnings announcements because larger firms more in the news (Scott 2009). This article uses market capitalization to represent size $\left(\mathrm{SIZE}_{\mathrm{i}, \mathrm{t}}\right)$. In technical analysis signal, there is a tendency of asymmetry reaction between buying (selling) signal (McKenzie 2007). This study complements the asymmetry reaction on technical analysis signal.

The second hypothesis predicts that reporting lag positively affect technical analysis performance. The empirical model presented as follows.

$R t b_{i, t}=d+d 1 . R l_{i, t}+d 2 . S_{Z} E_{i, t}+d 3$. Signal $_{i, t}+($ fixed effect) $+e 1$

Return based on technical analysis signal before earnings announcements is represented by $R t b_{i, t} \cdot R l_{i, t}$ is reporting lag firm $i$ in year $t . S I Z E i, t$ is market capitalization of firms $i$ in year $t$. Fixed effect controls years.

To improve the results, this study also uses robustness check. This step is needed to convince that different methodologies give the same conclusion. Related to return measurement, this study uses different price reference (closing and high-low) and different reaction measurement (market adjusted return and abnormal return based on market model). Related to the second hypothesis, this paper also separates buy and sell sample to show how the signal moderate the relation between reporting lag and technical analysis return. This step is expected to improve the discussion.

$R t b_{B S i, t}=f+f 1 . R l_{i, t}+f 2 . S I Z E_{i, t}+e 2$

$\mathbf{R t b}_{\mathrm{SBi}}\left(\mathbf{R t b}_{\mathrm{SSi}}\right)$ represent that technical analysis return is generated from price on buy (sell) signal before earnings announcements on stock $i$ on year $t$ compared to price on sell (buy) signal after earnings announcements.

\section{DATA ANALYSIS AND DISCUSSION}

Empirical support for this contention is provided in this section. This paper first documents the impact of timeliness and reporting lag of earnings announcements on the return of technical analysis signal before earnings announcements. Then, this research also enhances the quality of findings by conducting robustness test and exploring the implication of these results.

\section{Timeliness and Technical Analysis Signal}

This study believes an idea that late announcements stimulate different reactions from investors. Late announcements degrade earnings informativeness and generate low reaction on earningsannouncement dates. That phenomenon produce higher tendency of information leakage and produce higher price reaction before earnings announcements. More reactions produce reliable technical analysis signals before earningsannouncement dates, while lower reaction after earnings announcements generates less reliable signals (Sulistiawan and Hartono 2014).

Technical analysis return is positively skewed. Using central limit theorem, this study argue that 
Dedhy Sulistiawan: The impact of earnings-announcement ...

Table 2

Technical Analysis Return Based on Earnings Announcements Timeliness

\begin{tabular}{llccrr}
\hline $\begin{array}{c}\text { Technical Analysis } \\
\text { Return }\end{array}$ & $\begin{array}{c}\text { Timeliness of Earnings } \\
\text { Announcements }\end{array}$ & N & Mean & Std. Deviation & t-value Sig.(1 tail) \\
\hline \multirow{2}{*}{ Rtbi,t,close } & Early & 856 & 0.0378 & 0.15158 & -1.950 \\
& Late & 160 & 0.0783 & 0.25441 & $\left(^{* *}\right)$ \\
Rtbi,t,hl & Early & 856 & 0.0598 & 0.16206 & -1.922 \\
& Late & 160 & 0.1013 & 0.26432 & $\left(^{* *}\right)$ \\
ExRtbi,t,close & Early & 856 & 0.0299 & 0.14215 & -1.994 \\
& Late & 160 & 0.0688 & 0.23927 & $\left({ }^{* *}\right)$ \\
ExRtbi,t,hl & Early & 856 & 0.0472 & 0.15184 & -1.963 \\
& Late & 160 & 0.0871 & 0.24838 & $\left(^{* *}\right)$ \\
ARtbi,t,close & Early & 765 & 0.0315 & 0.15020 & -1.507 \\
& Late & 147 & 0.0623 & 0.23919 & $\left({ }^{*}\right)$ \\
ARtbi,t,hl & Early & 368 & 0.0341 & 0.08848 & -1.146 \\
& Late & 59 & 0.0747 & 0.26984 & $(\mathrm{n} . \mathrm{s})$ \\
\hline
\end{tabular}

$\overline{\text { Rtbi,t,close (Rtbi,t,hl) is calculated based on the difference between the closing (high and low) price on technical signal day before and }}$ after the earnings announcement.

ExRtbi,t,is Rtbi,t after adjusted by market return. ARtbi,t,is Rtbi,t after adjusted by expected return based on market model. ${ }^{* * * *},{ }^{* *},{ }^{*}$ indicate that the test is significant at the level of $1 \%, 5 \%$, and $10 \%$, respectively.

normality is not a crucial problem. That belief is also supported with the article of Brown and Warner (1985) that also gives evidence about the importance of alternative measurement to test the hypothesis to get conclusive results in measuring security return. To improve the results, this study also examines using many methods of return measurement. Using univariate test, $\mathrm{H} 1$ is tested using independent sample t-test. It is presented in Table 2.

Table 2 reports the difference technical analysis return based on the timeliness of announcements. Using different measurement of return, the table shows that late announcers produce higher technical analysis return than early announcer. Using $\mathrm{Rtb}_{\mathrm{i}, \mathrm{t}, \mathrm{close},}\left(\mathrm{Rtb}_{\mathrm{i}, \mathrm{thl}}\right)$ the return of late announcements $7.8 \%(10.13 \%)$, but that of early announcements is only $3.78 \%(5.98 \%)$. Using market adjusted return $\left(\right.$ ExRtb $\left._{\mathrm{i}, \mathrm{t}}\right)$, late announcements also generate bigger return than early announcements. The same results also presented by this research sample using ARt$b_{i, t, h l}$ and $A R t b_{i, t, c l o s e}$. Using equal variance which is not assumed, in all samples, except ARtb $\mathrm{b}_{\mathrm{i}, \mathrm{thl}} \mathrm{sam}$ ple, the differences are significant. Late (early) announcements generate higher (lower) technical analysis return. Based on this preliminary test, H1 is supported.

Improving the findings, this study complements the test of $\mathrm{H} 1$ by using ANOVA. The results are presented in Table 3. After controlling the impact of timeliness to technical analysis return using signal and size, the findings are presented in Table 3. In all methods, the timeliness of earnings announcements significantly affects technical analysis return before earnings announcements. The table also shows that interaction between timeliness and signal $(\mathrm{T} \times \mathrm{S})$ affect technical analysis return. It means that the relation of timeliness to technical analysis return is also affected by its signal (buy or sell signal). Using many measurement of return, this study implicitly presents the robust finding.

\section{Reporting Lag and Technical Analysis Signal}

Substantially, the first hypothesis is almost similar to the second one. If $\mathrm{H} 1$ focuses on the timeliness, then $\mathrm{H} 2$ on the reporting lag. Higher reporting lag indicates the tendency managements to delay information to public. Longer reporting lag stimulate more reaction before earnings announcements, then, price reactions are more easily detected by technical analysis signal. This study predicts that longer (shorter) reporting lag produce higher (lower) technical analysis return. Using panel least square, the results of these tests are presented in Table 4. That is unbalanced panel observation.

The tests on all samples above present evidence that reporting lag positively affect technical analysis return. Using $R t b_{i, t, c l o s e}$ and $R t b_{i, t, h l}$, regression equations produce t-value 1.793435 and 1.942372 in lag coefficient which are statistically significant at $5 \%$ for both of them. In samples that use ExRtb ${ }_{i, t, \text { lose }}$ and ExRtb $b_{i, t, h l}$, the tests show that $\mathrm{t}$ value in lag coefficients are 1.725654 and 1.861137 which are also significant at $5 \%$. For ARtb $b_{i, t, c l o s e}$ and $\mathrm{ARtb}_{\mathrm{i}, \mathrm{t}, \mathrm{hl}}$ sample, the $\mathrm{t}$ value are 1.701121 and 1.715616 which are statistically significant at $5 \%$. The results conclude that $\mathrm{H} 2$ is supported. 
Table 3

The Impact of Timeliness to Return of Technical Analysis Signal before Earnings Announcements

\begin{tabular}{lccccccc}
\hline \multicolumn{1}{c}{ Sources of } & & \multicolumn{3}{c}{ F-test } & & \\
Variance & Timeliness (T) & Size (Z) & Signal (S) & $\mathbf{T} \times \mathbf{Z}$ & $\mathbf{T} \times \mathbf{S}$ & $\mathbf{Z} \times \mathbf{S}$ & $\mathbf{T} \times \mathbf{Z} \times \mathbf{S}$ \\
Rtbi,t,close & 8.512 & 0.156 & 36.515 & 0.613 & 6.705 & 0.084 & 2.793 \\
sig. & 0.004 & 0.693 & 0.000 & 0.434 & 0.010 & 0.772 & 0.095 \\
Rtbi,t,hl & 9.526 & 0.331 & 32.814 & 1.704 & 5.342 & 0.379 & 2.804 \\
sig. & 0.002 & 0.565 & 0.000 & 0.192 & 0.021 & 0.539 & 0.094 \\
ExRtbi,t,close & 7.275 & 0.154 & 15.414 & 0.543 & 9.330 & 0.196 & 1.857 \\
sig. & 0.007 & 0.695 & 0.000 & 0.461 & 0.002 & 0.658 & 0.173 \\
ExRtbi,t,hl & 7.956 & 0.170 & 13.068 & 1.564 & 7.663 & 0.605 & 1.936 \\
sig. & 0.005 & 0.680 & 0.000 & 0.212 & 0.006 & 0.437 & 0.164 \\
ARtbi,t,close & 7.956 & 0.170 & 13.068 & 1.564 & 7.663 & 0.605 & 1.936 \\
sig. & 0.005 & 0.680 & 0.000 & 0.212 & 0.006 & 0.437 & 0.164 \\
ARtbi,t,hl & 6.323 & 0.077 & 14.963 & 0.449 & 6.527 & 0.001 & 1.349 \\
sig. & 0.012 & 0.781 & 0.000 & 0.503 & 0.011 & 0.975 & 0.246 \\
\hline
\end{tabular}

Rtbi,t,close (Rtbi,t,hl) is calculated based on the difference between the closing (high and low) price on technical signal day before and after the earnings announcement.

ExRtbi,t,is Rtbi,t after adjusted by market return.

ARtbi,t,is Rtbi,t after adjusted by expected return based on market model.

Timeliness, size, and signal is represented by $\mathrm{T}, \mathrm{Z}$, and $\mathrm{S}$.

Signal is a binary indicator variable equal to one if buy signal, zero otherwise.

Timeliness is a binary indicator variable equal to one if late, zero otherwise.

Size is determined using binary indicator variable equal to one if market capitalization is bigger than median, zero otherwise.

$* * *+* *$ indicate that the test is significant at the level of $1 \%, 5 \%$, and $10 \%$, respectively.

\section{Discussion}

Earnings announcement studies discuss the reaction on earnings announcements including factors that determine the reaction (Scott, 2009). Landsman et al. (2012) observe market reaction in many countries. The study of Mrying (2006) and DeFond et al. (2007) are also one of the examples. This study is also an earnings-announcement study. Although it is classical topic in accounting, this study expands the idea using technical analysis indicators to observe asymmetry reaction based on the duration of reporting lag. The use of technical analysis is an important part of this study, because earnings announcement and technical analysis are different issues. Using market microstructure theory, this study builds a bridge between those issues.

Technical analysis studies focus on technical analysis return (Milionis and Papanagioutu 2008; Metghalci et al. 2012). That is the profitability of technical analysis using time series data. This study develops technical analysis research by using event-studies in technical analysis research. This idea develops previous studies; Sulistiawan and Hartono (2014) and Sulistiawan et al. (2014). The first, its focus is on the reliability of technical analysis signal before and after earnings announcements. The second, its focus is on the role of technical analysis signal as competing information. This study develops it using report- ing lag and its impact to technical analysis return.

Using different measurement and statistical test, this study presents that timeliness of earnings announcements affect return of technical analysis signal before earnings announcements. Late (early) announcements produce higher (lower) technical analysis return because late announcements stimulate informed investors exploit preannouncement information. Noise traders who have no information will use the news as discounted information. To anticipate "buy on rumors sell on news" phenomena, this study recommend the noise traders to analyze preannouncement reaction using technical analysis before earnings announcements, especially for late earnings announcements. The idea is supported with data.

H1 is supported, but it doesn't mean that technical analysis signals from early earnings announcements are unreliable. The data shows us that technical analysis return from early announcements sample still produce positive return. It describes that technical analysis signal before earnings announcements is a profitable signal.

In the second hypothesis, reporting lag positively affect technical analysis return. Using panel least square, this study presents robust results. Furthermore, this paper also separates buy and sell signal sample. The separation is conducted to get deeper understanding about the result. Overall, $\mathrm{H} 2$ 
Table 4

The Impact of Reporting Lag to Technical Analysis Return

\begin{tabular}{|c|c|c|c|c|c|c|}
\hline $\begin{array}{c}\text { Technical } \\
\text { Analysis Return } \\
\end{array}$ & Intercept & Mcap & Rli,t & Signal & $d w$ & $\begin{array}{c}\text { Observation (Cross Section } \\
\text { Included) (Period) }\end{array}$ \\
\hline Rtbi,t,close & -0.032796 & -0.000002 & 0.000717 & 0.057445 & 1.672919 & 744 \\
\hline $\mathrm{t}$-value & -1.286007 & -1.090557 & 1.793435 & 5.571647 & & 265 \\
\hline Sig & * & n.s & ** & $* * *$ & & 5 \\
\hline Rtbi,t,hl & -0.015044 & -0.000002 & 0.000806 & 0.058445 & 1.673630 & 744 \\
\hline $\mathrm{t}$-value & -0.568204 & -1.255633 & 1.942372 & 5.460105 & & 265 \\
\hline Sig & n.s & n.s & ** & $* * *$ & & 5 \\
\hline ExRtbi,t,close & -0.016962 & -0.000001 & 0.000646 & 0.022248 & 1.767776 & 744 \\
\hline $\mathrm{t}$-value & -0.709776 & -0.787355 & 1.725654 & 2.302680 & & 265 \\
\hline sig & n.s & n.s & ** & ** & & 5 \\
\hline ExRtbi,t,hl & -0.002076 & -0.000002 & 0.000724 & 0.021717 & 1.761678 & 744 \\
\hline t-value & -0.083679 & -1.194776 & 1.861137 & 2.165079 & & 265 \\
\hline Sig & n.s & n.s & ** & ** & & 5 \\
\hline ARtbi,t,close & -0.020506 & -0.000001 & 0.000650 & 0.026266 & 1.785061 & 741 \\
\hline $\mathrm{t}$-value & -0.842800 & -0.906327 & 1.701121 & 2.678654 & & 265 \\
\hline Sig & n.s & n.s & ** & $* * *$ & & 5 \\
\hline ARtbi,t,hl & -0.014557 & -0.000002 & 0.000908 & 0.007806 & 1.030404 & 411 \\
\hline $\mathrm{t}$-value & -0.447449 & -1.107529 & 1.715616 & 0.612894 & & 168 \\
\hline Sig & n.s & n.s & ** & n.s & & 5 \\
\hline
\end{tabular}

Rtbi,t,close (Rtbi,t,hl) is calculated based on the difference between the closing (high and low) price on technical signal day before and after the earnings announcement.

ExRtbi,t,is Rtbi,t after adjusted by market return.

ARtbi,t,is Rtbi,t after adjusted by expected return based on market model.

Signal is a binary indicator variable equal to one if buy signal, zero otherwise.

Mcap is the natural logarithm of market capitalization of firm $i$ in year $t$.

$\mathrm{Rli}, \mathrm{t}$ is reporting lag of firm $\mathrm{i}$ in year $\mathrm{t}$.

**t, ${ }^{*+*},{ }^{*}$ indicate that the test is significant at the level of $1 \%, 5 \%$, and $10 \%$, respectively.

is supported, but when it separates buy and sell signal sample, it finds that the impact of reporting lag is not significant. It means that the signal moderates the relation between reporting lag and technical analysis signal. One main reason why these findings are not hypothesized is because of lack of supporting theory to explain the moderating effect of technical analysis signal. However, Mian and Sankarasguruswamy (2012) use sentiment as determinant of ERC. This study may adopt those articles to analyze the robustness test results. When recognizing buy (sell) signal as a good (bad) sentiment indicator, the relation between reporting lag and technical analysis return is driven by shortterm sentiment.

\section{CONCLUSION, IMPLICATION, SUGGES- TION, AND LIMITATIONS}

There are two main conclusions in this study as the following. First, timeliness of earnings announcements affects the returns of technical analysis signals before earnings announcements. Technical analysis return is higher (lower) for late (early) announcers. Second, reporting lag positively affect the returns of technical analysis signals before earnings announcements. The impact of reporting lag to technical analysis return is bigger when the signal is buy.

These findings indicate that "buy on rumors and sell on news" phenomenon is bigger for firms that tend to delay earnings announcements. News on earnings announcements are discounted when there are preannouncements reactions. To anticipate this problem, this study uses technical analysis signal. The results are as expected.

These findings have implications to market microstructure theory. Informed investors reaction can be detected by noise traders using technical analysis signal. That phenomenon shows that technical analysis signal synchronizes private to public information. In short, this study may build a bridge between earnings-announcements timing and technical analysis studies. This paper also has methodological implications in terms of identifying reaction of announcements using technical analysis signal.

The prediction of this study is supported by the data. Although the results are robust, this study should be developed in several aspects. First, future researches may use inter-countries 
analysis. Second, next researchers may also use relative announcements as the main dependent variables. Reporting lag may relate to the complexity of a company or the ability of auditors, but relative reporting lag are controlled by its entity. The relative reporting lag can be calculated based on the duration between auditor dates and earnings announcement dates. Finally, future researches may use more complicated technical analysis signal, including the use of trading volume to enrich the discussion. Landsman et al. (2012) show that earnings announcements stimulate reaction on both price and stock volume around the world.

\section{REFERENCES}

Black, F 1986, 'Noise', Journal of Finance, vol. 41, no. 3, pp. 529-543.

Brown, SJ \& Warner, JB 1985, 'Using daily stock returns: The case of event studies', Journal of Financial Economics vol. 14, no. 1, pp. 3-31.

DeFond, M Hung, M \& Trezevant, R 2007, 'Investor protection and the information content of annual earnings announcements: International evidence', Journal of Accounting $\mathcal{E}$ Economics, vol. 43 , no. 1, pp. 37-67.

Fifield, SGM, Power, DM \& Sinclair, CD 2005, 'An analysis of trading strategies in Eleven European Stock Markets', The European Journal of Finance, vol. 11, no. 6 ,pp. 531-548.

Flanegin FR \& Rudd DP 2005, 'Should investments professors join the 'crowd", Managerial Finance, vol. 31 , no. 5 , pp. 28-37.

Francis J, Schipper K \& Vincent L 2002, ‘Earnings announcements and competing information', Journal of Accounting and Economics, vol. 33, no. 3, pp. 313-342.

Hartono J \& Sulistiawan D 2014, 'The market quality to technical analysis performance: Intercountry analysis', Gadjah Mada International Journal of Business, vol. 16, no. 3, pp. 243-254.

Hartono J \& Sulistiawan D 2015, 'Performance of Technical Analysis in Declining Global Markets', Global Journal of Business Research, vol. 9, no. 2, forthcoming.

Haw IM, Qi D \& Wu YW 2000, 'Timeliness of annual report releases and market reaction to earnings announcements in an emerging capital market: The case of China', Journal of International Financial Management and Accounting, vol. 11, no. 2, pp. 108-131.

Kross W 1982, 'Earnings announcement time lags, and stock prices', Journal of Business Research, vol. 9, no. 3, pp. 267-281.
Landsman WR, EL, Maydew EL \& Thornock JR 2012, 'The information content of annual earnings announcements and mandatory adoption of IFRS', Journal of Accounting and Economics, vol. 53, no. 1-2, pp. 34-54.

McKenzie MD 2007, 'Technical trading rules in emerging markets and the 1997 Asian Currency Crises', Emerging Markets Finance and Trade, vol. 43 , no. 4 , pp. 46-73.

Metghalchi, M, Chang Y \& Gomez XG 2012, 'Technical analysis of the Taiwanese Stock Market', International Journal of Economics and Finance, vol. 4, no. 1, pp. 90-102.

Mian GM \& Sankaraguruswamy S 2012, 'Investor sentiment and stock market response to earnings news', Accounting Review, vol. 87, no. 4, pp. 1357-1384.

Milionis AE \& Papanagiotou E 2008, 'On the use of moving average trading rule test for weak form efficiency in capital markets', Review of Banking, Finance and Monetary Economics, vol. 37, no. 2, pp. 181-201.

Mrying M 2006, 'The relationship between returns and unexpected earnings: A global analysis by accounting regimes', Journal of International Accounting, Auditing and Taxation, vol. 15, no. 15, pp. 92-108.

Scott, WR 2009, Financial Accounting Theory, Prentice Hall, Toronto.

Sengupta P 2004, 'Disclosure timing: Determinants of quarterly earnings release dates', Journal of Accounting and Public Policy, vol. 23, no. 6, pp. 457-482.

Sulistiawan D \& Hartono J 2014, 'Can technical analysis signals detect price reaction around earnings announcement?: Evidence from Indonesia', The International Journal of Business and Finance Research, vol. 8, no. 1, pp. 113-123.

Sulistiawan D, Hartono J, Tandelilin E \& Supriyadi 2014, 'Earnings announcements and competing information: Indonesian evidence', Indonesian Journal of Economics and Business, Vol. 29, No. 1

Whittred G 1980, 'Audit qualification and the timeliness of corporate annual reports', Accounting Review, vol. 55, no. 4, pp. 563-577.

Wirakusuma MG 2006, 'The impact of timeliness of financial statement publication to accounting income quality in Indonesian stock market', The Indonesian Journal of Accounting Research, vol. 11, no. 3, pp. 286-310.

\section{ACKNOWLEDGMENT}

*) Earlier draft of this article was presented in The $3^{\text {rd }}$ Economics and Business Research Festival Se- 
Dedhy Sulistiawan: The impact of earnings-announcement ...

minar at Satya Wacana Christian University. This article is based on research project for doctoral student funded by DIKTI. The comments of Sarmini
(State University of Surabaya) and Raditya Sukmana (Airlangga University) are gratefully acknowledged. 


\section{Journal of Economics, Business, \& Accountancy}
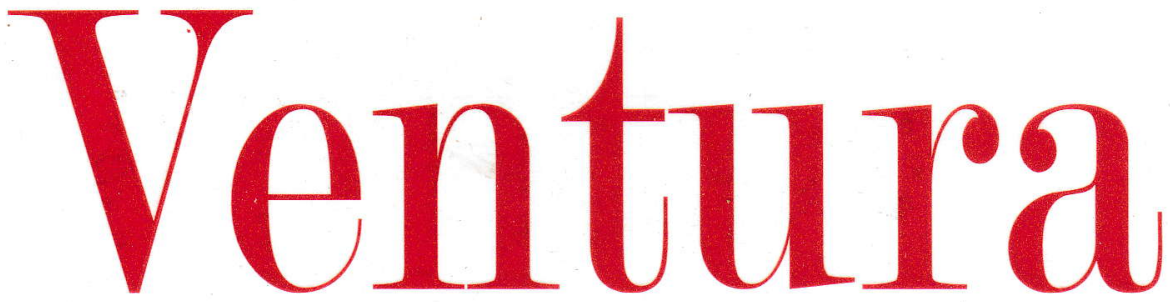

\section{Volume 18, No. 2, August - November 2015}

The determinant effect of industry sub-sectors on the gross regional domestic product in Maluku

Teddy Christianto Leasiwal

Development formulation of crafts weaving batik ikat East Java: Strategic block and interconnection

Didiek Tranggono, Jojok Dwiridhotjahjono, Maria Indira Aryani, Resa Rasyidah

The impact of earnings-announcement timing on technical analysis signal: The case of Indonesia

Dedhy Sulistiawan

Ownership concentration and bank risk (A study on banking sectors in Indonesia)

Etikah Karyani, Sidharta Utama

Customers' perceived value towards the service in Islamic banking: Confirmatory factor analysis Suryani

Big-five personality as a moderating variable in the relationship of $\mathrm{CEO} \square \mathrm{s}$ perception and the compensation received toward $\mathrm{CEO} \square \mathrm{s}$ desire to leave the company voluntarily

Lindrianasari

The effect of job stress and job motivation on employees' performance through job satisfaction (A study at PT. Jasa Marga (Persero) Tbk. Surabaya - Gempol branch)

Noermijati, Diana Primasari

Information quality, homophily, and risk propensity: Consumer responses to online hotel reviews Sony Kusumasondjaja

The exploration of professionalism understanding of accounting educators' Melinda Ibrahim, Unti Ludigdo, Gugus Irianto

The role of investor protection in corporate governance and accounting harmonization: Crosscountry analysis in Asia

Ratna Wardhani

Fraudulent financial reporting in public companies in Indonesia: An analysis of fraud triangle and responsibilities of auditors

Sri Astuti, Zuhrohtun, Kusharyanti

The effects of auditor reputation, financial condition, and potential intensive economy on artificial auditor rotation

Junaidi, Bambang Hartadi, Priyo Sajarwo Yurianto, Nurdiono

The role of auditor in whistleblower system: The cases in Indonesia Nurul Hasanah Uswati Dewi, Djuwito, Romanus Wilopo 
Published by :

Center for Research and Community Services (PPPM)

In Cooperation with the Association of Commercial Banks in East Java

(Perhimpunan Bank-Bank Umum Nasional Jawa Timur-Perbanas Jatim)

\title{
Editor-in-Chief :
}

Tatik Suryani

\section{Editors on Board :}

Abdul Mongid, Yudi Sutarso, Luciana Spica Almilia, Soni Harsono,

Tjahjani Prawitowati

\section{Editor of Language \\ Djuwari}

Management \& Publishing Team :

Tri Suhartuti

Erlinda Pudji Setyawati

Hariadi Yutanto

\section{Secretariat :}

PPPM STIE Perbanas Surabaya

Jl. Nginden Semolo 34-36 Surabaya, 60118

Phone: +62 31 5992985, 5947151/52; Fax. +62 31 5992985, 5935937

e-mail: venturaperbanas@yahoo.com, ventura@perbanas.ac.id

\author{
Published quarterly \\ (April - July, August - November, and December - March) \\ This journal publication can be viewed in \\ Http://garuda.dikti.go.id \\ http://journal.perbanas.ac.id
}

\footnotetext{
Editors receive articles of research, conceptual analysis, and book analysis on Economics, Business and Accountancy. The articles should be original, not reflecting the editors's opinion. The authors must be responsible for the content of the articles published in this journal. Editors deserve to receive, decline and edit the articles without changing the main ideas.
} 


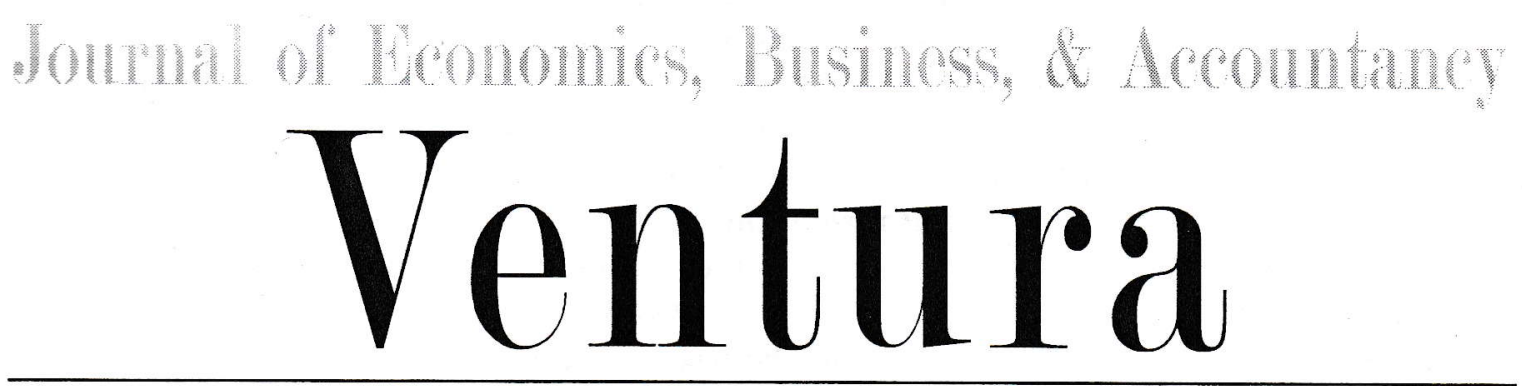

Accreditation No. 80/DIKTI/Kep/2012

The determinant effect of industry sub-sectors on the gross regional domestic product in Maluku

Teddy Christianto Leasiwal

Development formulation of crafts weaving batik ikat East Java: Strategic block and interconnection

Didiek Tranggono, Jojok Dwiridhotjahjono, Maria Indira Aryani, Resa

Rasyidah

The impact of earnings-announcement timing on technical analysis signal:

The case of Indonesia

Dedhy Sulistiawan

$179-188$

Ownership concentration and bank risk (A study on banking sectors in

Indonesia)

Etikah Karyani, Sidharta Utama

$189-200$

Customers' perceived value towards the service in Islamic banking:

Confirmatory factor analysis

Suryani

$201-212$

Big-five personality as a moderating variable in the relationship of $\mathrm{CEO}^{\text {ee }} \mathrm{S}$ perception and the compensation received toward $\mathrm{CEO}^{\text {"es }} \mathrm{s}$ desire to leave the company voluntarily

Lindrianasari

The effect of job stress and job motivation on employees' performance through job satisfaction (A study at PT. Jasa Marga (Persero) Tbk. Surabaya Gempol branch)

Noermijati, Diana Primasari

$231-240$

Information quality, homophily, and risk propensity: Consumer responses to online hotel reviews

Sony Kusumasondjaja

The exploration of professionalism understanding of accounting educators' Melinda Ibrahim, Unti Ludigdo, Gugus Irianto

The role of investor protection in corporate governance and accounting harmonization: Cross-country analysis in Asia

Ratna Wardhani 
Fraudulent financial reporting in public companies in Indonesia: An analysis of fraud triangle and responsibilities of auditors

Sri Astuti, Zuhrohtun, Kusharyanti

The effects of auditor reputation, financial condition, and potential intensive economy on artificial auditor rotation

Junaidi, Bambang Hartadi, Priyo Sajarwo Yurianto, Nurdiono

The role of auditor in whistleblower system: The cases in Indonesia

Nurul Hasanah Uswati Dewi, Djuwito, Romanus Wilopo 